\title{
JAK2 wt Allele
}

National Cancer Institute

\section{Source}

National Cancer Institute. JAK2 wt Allele. NCI Thesaurus. Code C51085.

Human JAK2 wild-type allele is located within 9p24 and is approximately $143 \mathrm{~kb}$ in length.

This allele, which encodes tyrosine-protein kinase JAK2 protein, plays a role in interleukin 3 signal transduction. An allelic variant of the JAK2 gene, which exhibits a dominant gain of function mutation, is associated with several myeloproliferative disorders including polycythemia vera, essential thrombocythemia and idiopathic myelofibrosis. 